Article

\title{
Construction of the 1,2-Dialkenylcyclohexane Framework via Ireland-Claisen Rearrangement and Intramolecular Barbier Reaction: Application to the Synthesis of $( \pm)$-Geijerone and a Diastereoisomeric Mixture with Its 5-Epimer
}

\section{Dawei Liang, Nana Gao, Wei Liu and Jinhua Dong *}

Key Laboratory of Structure-Based Drug Design and Discovery, Ministry of Education, Shenyang Pharmaceutical University, Shenyang 110016, Liaoning, China; E-Mails: ldawei@yahoo.com (D.L.); gaonana89@126.com (N.G.); lwnever@126.com (W.L.)

* Author to whom correspondence should be addressed; E-Mail: dongjh66@hotmail.com;

Tel.: +86-24-2398-6402; Fax: +86-24-2390-4249.

Received: 17 December 2013; in revised form: 14 January 2014 / Accepted: 15 January 2014 /

Published: 20 January 2014

\begin{abstract}
The elemene-type terpenoids, which possess various biological activities, contain a syn- or anti-1,2-dialkenylcyclohexane framework. An efficient synthetic route to the syn- and anti-1,2-dialkenylcyclohexane core and its application in the synthesis of $( \pm)$-geijerone and its diastereomer is reported. Construction of the syn- and anti-1,2-dialkenyl moiety was achieved via Ireland-Claisen rearrangement of the $(E)$-allylic ester, and the cyclohexanone moiety was derived from the iodoaldehyde via intramolecular Barbier reaction. The synthetic strategy allows rapid access to various epimers and analogues of elemene-type products.
\end{abstract}

Keywords: 1,2-dialkenylcyclohexane; $( \pm)$-geijerone; Ireland-Claisen rearrangement; intramolecular barbier reaction; synthesis

\section{Introduction}

Natural products continue to attract intense attention due to their various bioactivities and they have played a vital role in the field of drug discovery in recent decades. Most of the drugs in the clinical market today are inspired by or derived from natural sources [1]. $\beta$-Elemene, $\gamma$-elemene, $\delta$-elemene, geijerene, ineleganene, shyobunone and dehydromelitensin are natural terpenoids with a syn- or 
anti-1,2-dialkenylcyclohexane skeleton (Figure 1), and exist in various essential oils [2-9]. These compounds or their racemic mixtures have been shown to inhibit tumor cell growth in vitro and in vivo [10-15]. The mixture of $\beta$-elemene, $\gamma$-elemene and $\delta$-elemene has been put into clinical trials in cancer patients in China [16,17].

A lot of efforts have been made towards the synthesis of these compounds due to their specific structures and important biological activities. For instance, Wu's group reported the synthesis of elemene derivatives starting from carvone, employing a double Michael reaction as the key step [18,19]. In addition, other colleagues have reported their synthetic strategies for the synthesis of $\beta$-elemene, including Cope rearrangement, Ireland-Claisen rearrangement, doubly diastereo-differentiating folding and allylic strain-controlled intramolecular ester enolate alkylation [20-24].

Structurally, $( \pm)$-geijerone (1, Figure 1) contains a highly functionalized anti-1,2-dialkenylcyclohexane moiety and the 7-carbonyl group of $( \pm$ )-geijerone (1) is beneficial for derivatization reactions. Therefore, $( \pm$ )-geijerone $(\mathbf{1})$ could be considered as a common precursor in the synthesis of elemene-type terpenoids. Kim utilized an intramolecular ester enolate alkylation to construct ( \pm )-geijerone (1) and synthesized ã-elemene by starting from a rare lactol [25]. Another synthesis of $( \pm$ )-geijerone (1) was reported by Yoshikoshi, using the Wieland-Miescher ketone as the starting material [26]. As a part of our synthetic studies on direct construction of the syn- and anti-1,2dialkenylcyclohexane skeleton and bioactive elemene-type terpenoids we describe herein a novel and alternative synthesis of a mixture of two diastereomers of $( \pm)$-geijerone (1) by starting from the chainlike and commercially available geraniol (2).

Figure 1. Structures of elemene-type terpenoids and ( \pm )-geijerone (1).

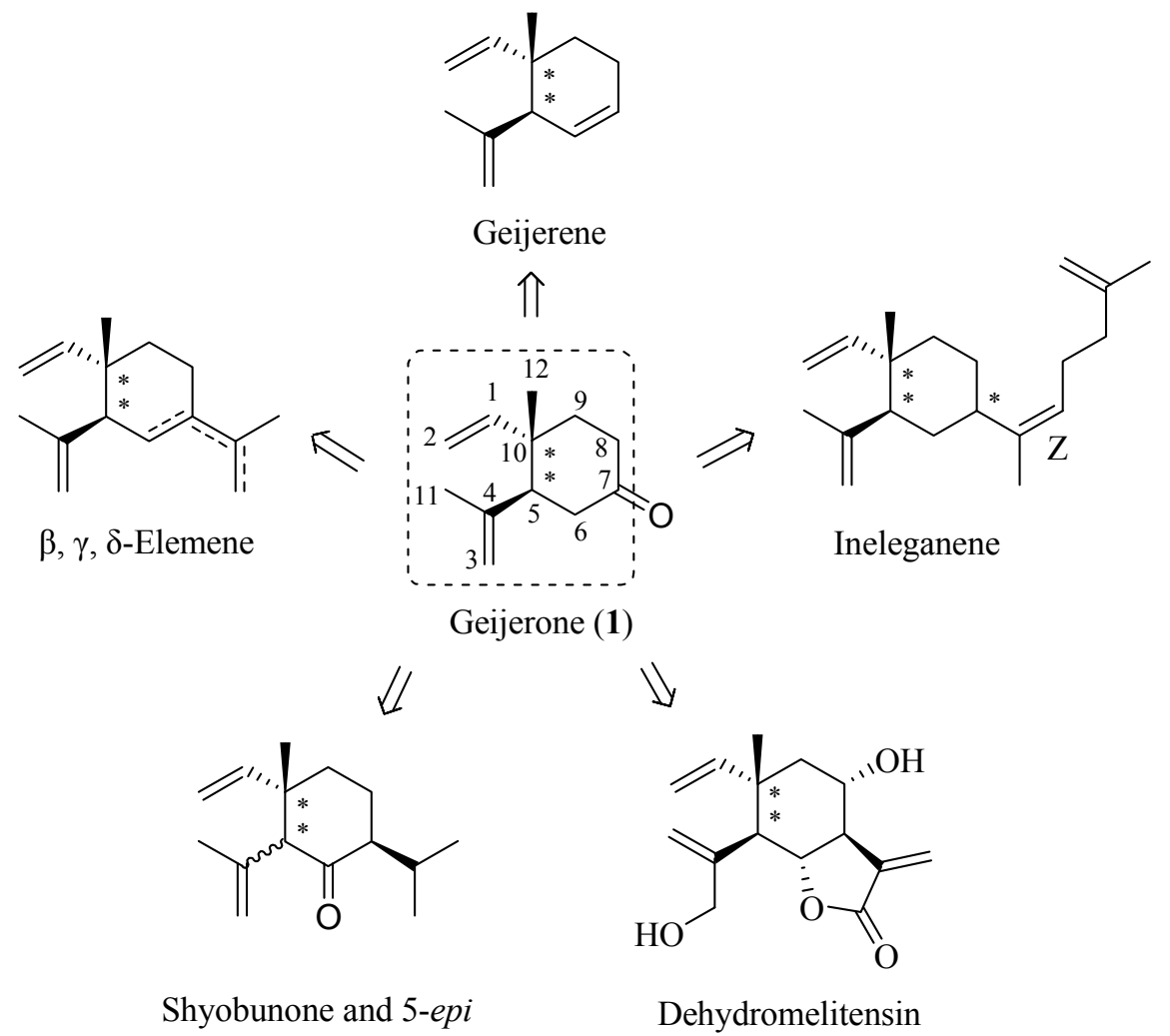




\section{Results and Discussion}

The retrosynthetic analysis is outlined in Scheme 1. $( \pm)$-Geijerone could be synthesized from 14a via intramolecular Barbier reaction and subsequent oxidation. The conversion of 11a to 14a could be achieved by conventional methods. The anti-1,2-dialkenyl carboxylic acid 11a could be constructed from $(E)$-allylic ester $\mathbf{1 0}$ using an Ireland-Claisen rearrangement as the key step. The ester $\mathbf{1 0}$ could be derived from geraniol (2) and 3-methyl-3-buten-1-ol (8).

Scheme 1. Retrosynthetic analysis of $( \pm)$-geijerone (1).<smiles>C=CC(=C)C(=C)C1CC(=O)CC[C@]1(C)C=C</smiles>

Geijerone (1)

15

14a
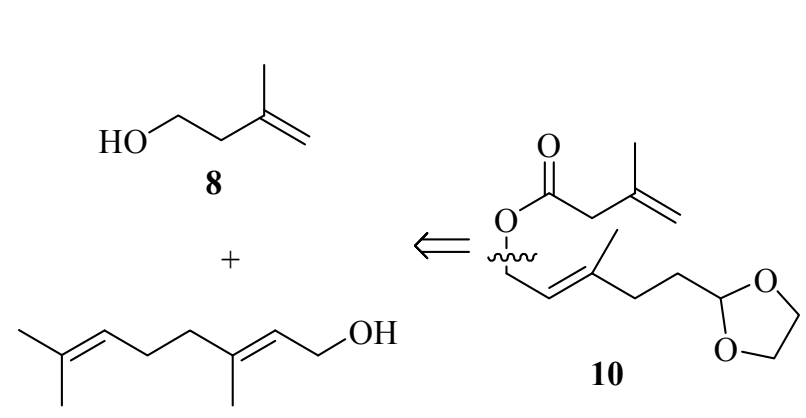

10<smiles>C1=CCCCCC1</smiles>

Geraniol (2)

Our synthesis commenced with the construction of the key $(E)$-allylic ester intermediate $\mathbf{1 0}$ (Scheme 2). Protection of the hydroxyl group in geraniol (2) by acetyl chloride in pyridine gave 3 in $84 \%$ yield. Selective epoxidation of 3 at the double bond between C-6, C-7 with $m$-chloroperoxybenzoic acid afforded 4 (72\%), and the ring cleavage reaction was undertaken with periodic acid to afford aldehyde $5(80 \%)$ [27,28]. Next, protection of the aldehyde group of 5 gave acetal $\mathbf{6}$ in $90 \%$ yield, and removal of the acetyl group of $\mathbf{6}$ with anhydrous potassium carbonate afforded alcohol 7 in $82 \%$ yield. The oxidation of 8 to acid 9 (58\%) was achieved with Jones' reagent. Finally, the subsequent esterification reaction of 7 and 9 in the presence of 1-(3-dimethylaminopropyl)-3-ethylcarbodiimide hydrochloride (EDCI) (1 equiv.) and 4-dimethylaminepyridine (DMAP) (0.05 equiv.) gave the desired ester $\mathbf{1 0}$ in $42 \%$ yield.

With ester 10 in hand, our first challenge was to construct the 1,2-dialkenyl moiety. We chose to accomplish this goal by the Ireland-Claisen rearrangement strategy. The rearrangement of ester $\mathbf{1 0}$ to acid 11 was conducted with lithium diisopropylamide (LDA) (2 equiv.) and chlorotrimethylsilane (TMSCl, 2 equiv.) at $-78{ }^{\circ} \mathrm{C}$ in anhydrous tetrahydrofuran, followed by a conventional operation. A proposed mechanism according to Ireland-Claisen rearrangement was outlined in Scheme 3 [29]. The formation of preferential configuration of the $(E)$-silyl enol ether could help to rationalize the possible six-membered, acyclically advantage chair-like transition state. Further the [3,3]-sigmatropic rearrangement of the (E)-silyl enol ether afforded the syn- and anti-1, 2-dialkenyl moiety in acid $\mathbf{1 1}$ as a mixture inseparable by silica gel chromatography. From the ${ }^{1} \mathrm{H}-\mathrm{NMR}$ results, the diastereomeric ratio 
of anti 11a/syn 11b could be readily deduced from the double-double signals for the vinyl proton at $\delta$ $5.84 / 6.05(J=10.8,17.5 \mathrm{~Hz},-\mathrm{CH}=)$. These ${ }^{1} \mathrm{H}-\mathrm{NMR}$ results were in agreement with those reported in the literature [21]. Koch et al. have demonstrated that the use of Lewis acid results in a highly diastereoselective rearrangement of allylic esters [30]. Thus, by using this protocol, we closely investigated the application of several Lewis acid catalysts to optimize the Claisen-Ireland rearrangement, and the results were summarized in Table 1. It was found that the anti diastereomer 11a was the major product ( $\mathrm{dr}=2: 1$, entry 1$)$ when no Lewis acid catalyst was used, while the presence of various Lewis acids was unfavorable for improving the diastereoselectivity in this substrate. Other possible conditions to improve the diastereoselectivity were not screened.

Scheme 2. Construction of the key intermediate $(E)$-allylic ester $\mathbf{1 0}$.

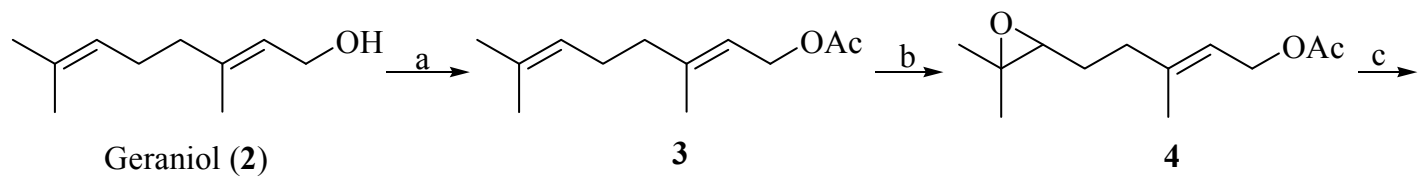

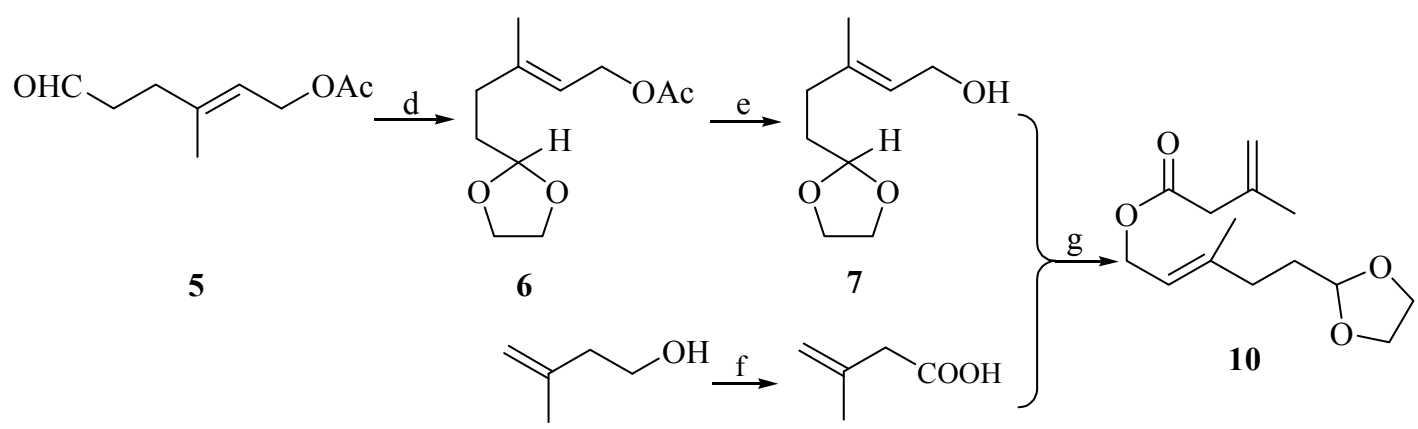

8

9

Reagents and conditions: (a) $\mathrm{CH}_{3} \mathrm{COCl}$, pyridine, $0{ }^{\circ} \mathrm{C}-$ r.t. $(84 \%)$; (b) $m$-CPBA, $\mathrm{CH}_{2} \mathrm{Cl}_{2},-5-0{ }^{\circ} \mathrm{C}(72 \%)$; (c) $\mathrm{HIO}_{4} \cdot 2 \mathrm{H}_{2} \mathrm{O}$, THF, $\mathrm{Et}_{2} \mathrm{O}, 0{ }^{\circ} \mathrm{C}(80 \%)$; (d) glycol, benzene, $p$ - $\mathrm{TsOH}\left(\right.$ cat.), reflux, $5 \mathrm{~h}(90 \%)$; (e) $\mathrm{K}_{2} \mathrm{CO}_{3}$ (cat.), $\mathrm{CH}_{3} \mathrm{OH}$, r.t., 12 h (82\%); (f) Jones reagent (58\%); (g) EDCI+DMAP (cat.), $\mathrm{CH}_{2} \mathrm{Cl}_{2}$, r.t, 12 h (42\%).

Scheme 3. Proposed advantage transition state of acid $\mathbf{1 1}$ from ester $\mathbf{1 0}$ via Ireland-Claisen rearrangement.

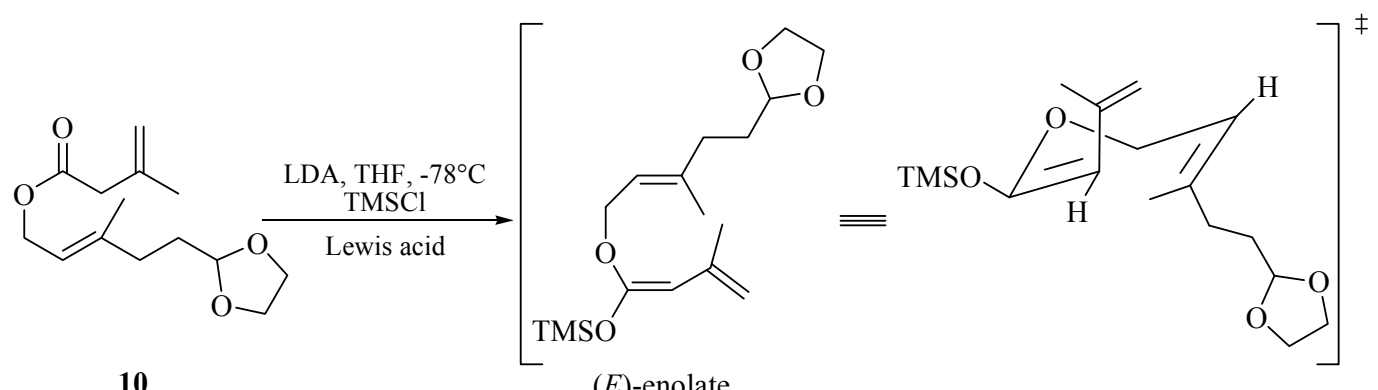

10

(E)-enolate

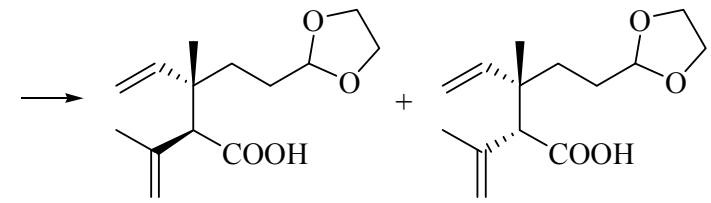

11a 
Table 1. Lewis acid-catalyzed Ireland-Claisen rearrangement of ester $\mathbf{1 0 .}$

\begin{tabular}{cccc}
\hline Entry $^{\mathbf{a}}$ & Lewis acid & Yield(\%) $^{\mathbf{b}}$ & $\mathbf{d r}^{\mathbf{c}}$ \\
\hline 1 & None & $72 \%$ & $2: 1$ \\
2 & $\mathrm{TMSOTf}^{\mathbf{c}}$ & $94 \%$ & $1: 1$ \\
3 & $\mathrm{BF}_{3}-\mathrm{Et}_{2} \mathrm{O}$ & $24 \%$ & $1: 1$ \\
4 & $\mathrm{ZnCl}_{2}$ & $75 \%$ & $1: 1$ \\
5 & $\mathrm{SnCl}_{4}$ & $91 \%$ & $1: 1$ \\
\hline
\end{tabular}

${ }^{\mathrm{a}}$ Reagents: Ester 10: LDA: TMSCl: Lewis acid $=1.0$ equiv.: 2.0 equiv.: 2.0 equiv.: 0.1 equiv.; ${ }^{\mathrm{b}}$ Isolated yields from 10; ${ }^{\mathrm{c}}$ Diastereomeric ratio (anti/syn) was calculated by ${ }^{1} \mathrm{H}-\mathrm{NMR}$ analysis of the purified mixture 11.

Subsequenr reduction of acid 11 with lithium aluminium hydride $\left(\mathrm{LiAlH}_{4}\right)$ gave a diastereomeric mixture of alcohols 12 in $83 \%$ yield. The diastereomeric separation of the mixture of alcohols was attempted by esterification of $\mathbf{1 2}$ with chiral $O$-acetyl mandelic acid, but the result was not ideal. Treatment of 12 with tosyl chloride gave a mixture of sulfonic esters 13, which after iodination and subsequent acetal deprotection provided a mixture of diastereoisomeric compounds 14, which was unstable during long-term storage. The diastereoisomers of 11-14 were difficult to separate by silica gel column chromatography, and various attempts to achieve the separation of the diastereoisomers using an appropriate chromatographic column size were undertaken. These methods have not been successful so far and the diastereomeric ratio of $\mathbf{1 4}$ was only raised to 3:1 (by ${ }^{1} \mathrm{H}-\mathrm{NMR}$ analysis). Subsequently, the cyclization of $\mathbf{1 4}$ occurred in the presence of $n$-BuLi via intramolecular Barbier reaction [31-36] to give a diastereomeric mixture of alcohols 15 (38\%). The direct addition of $n$-BuLi to $\mathbf{1 4}$ might be the cause for the low yield. Further optimization of this reaction is not described in this communication. Finally, compound $\mathbf{1 5}$ was oxidized by pyridinium chlorochromate (PCC), affording a mixture of 1 and its 5-epimer (60\%) (Scheme 4).

Scheme 4. Synthesis of $( \pm$ )-geijerone (1) and a diastereoisomeric mixture with its 5-epimer.

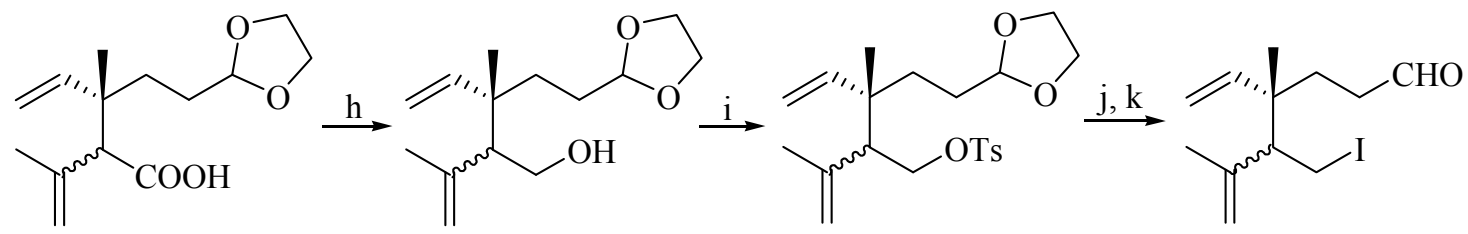

11

12

13

14

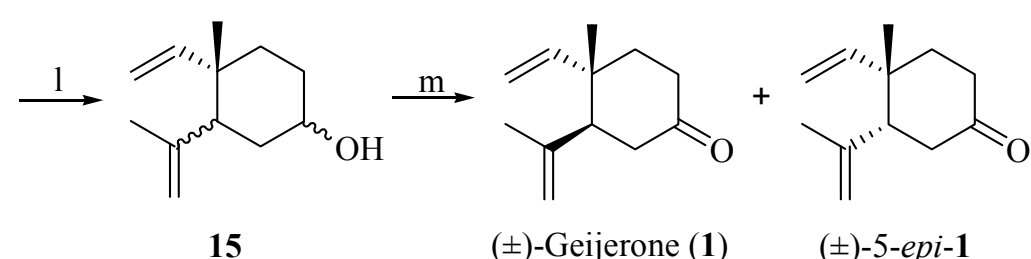

Reagents and conditions: Reagents and conditions: (h) $\mathrm{LiAlH}_{4}$, THF, $0{ }^{\circ} \mathrm{C}-$ r.t. and reflux (83\%); (i) $p$-TsCl, $\mathrm{CH}_{2} \mathrm{Cl}_{2}$, pyridine, r.t.; (j) NaI, acetone, reflux in the dark for $40 \mathrm{~h}$; (k) $p$ - TsOH (cat.), acetone $\left(10 \% \mathrm{H}_{2} \mathrm{O}\right), 1 \mathrm{~h}$ (23\%, 3 steps); (1) $n$-BuLi, $-78^{\circ} \mathrm{C}$ (38\%); (m) PCC, $\mathrm{CH}_{2} \mathrm{Cl}_{2}$, r.t., 2 h (60\%). 


\section{Experimental}

\section{General Information}

Several commercially available solvents were dried by standard procedures before use: pyridine $(\mathrm{NaOH})$, THF $(\mathrm{Na})$, acetonitrile $\left(\mathrm{CaCl}_{2}\right)$. Other commercial sources were used without further purification. ${ }^{1} \mathrm{H}-\mathrm{NMR}$ and ${ }^{13} \mathrm{C}-\mathrm{NMR}$ spectra were recorded with Bruker ARX-300 (300 MHz for ${ }^{1} \mathrm{H}-\mathrm{NMR}$ and $150 \mathrm{MHz}$ for ${ }^{13} \mathrm{C}-\mathrm{NMR}$ ) and Bruker ARX-600 spectrometers using TMS as internal standard (chemical shifts in $\delta$ values, $J$ in Hz). Low-resolution MS and high-resolution MS data were obtained on Agilent-6120 Quadruple LC/MS and Agilent-6520 QTOF LC/MSD spectrometer, respectively, using ESI ionization. Column chromatography was performed on silica gel (200-300 mesh, Qingdao Haiyang Chemical Co., Ltd, Qingdao, China). Analytical TLC was performed on plates precoated with silica gel (GF254, $0.25 \mathrm{~mm}$, Qingdao Haiyang Chemical Co., Ltd.) and iodine vapor was used to develop color on the plates.

3-Methyl-3-butenoic Acid (9). To a stirred solution of $8(6.0 \mathrm{~g}, 69.7 \mathrm{mmol})$ in acetone $(200 \mathrm{~mL})$ the Jones reagent $(36.5 \mathrm{~mL}, 97.5 \mathrm{mmol})$ was dropwise added at $0{ }^{\circ} \mathrm{C}$ for $2 \mathrm{~h}$, and the resulting mixture was stirred at room temperature for another $6 \mathrm{~h}$. The reaction mixture was quenched with $\mathrm{H}_{2} \mathrm{O}(50 \mathrm{~mL})$, and most of acetone was evaporated under reduced pressure. The residue was extracted with $\mathrm{Et}_{2} \mathrm{O}$ $(3 \times 20 \mathrm{~mL})$, The combined ethereal solution was washed with saturated aqueous $\mathrm{NaHCO}_{3}$ solution . The combined aqueous layer was acidified with diluted hydrochloric acid $(2 \mathrm{M})$ to $\mathrm{pH}=3$, and then extracted again with $\mathrm{Et}_{2} \mathrm{O}(2 \times 20 \mathrm{~mL})$. All combined ethereal solution was washed successively by water, brine and dried (anhydrous $\mathrm{MgSO}_{4}$ ), concentrated in vacuo. The residue was distilled to give $3.3 \mathrm{~g}(58 \%)$ of acid 9, colorless oil, b.p. $=86-88{ }^{\circ} \mathrm{C}(25 \mathrm{mmHg}) .{ }^{1} \mathrm{H}-\mathrm{NMR}\left(300 \mathrm{MHz}, \mathrm{CDCl}_{3}\right)$ : $\delta=10.14(\mathrm{~s}, 1 \mathrm{H},-\mathrm{COOH}) ; 4.96\left(\mathrm{dd}, J=1.5,10.8 \mathrm{~Hz},=\mathrm{CH}_{2}\right) ; 3.09\left(\mathrm{~s}, 2 \mathrm{H},-\mathrm{CH}_{2}-\right) ; 1.84\left(\mathrm{~s}, 3 \mathrm{H},-\mathrm{CH}_{3}\right)$.

(E)-3,7-Dimethylocta-2,6-dienyl Acetate (3). To a stirred solution of geraniol (2, $30.0 \mathrm{~g}, 194.8 \mathrm{mmol})$ in pyridine $(80 \mathrm{~mL})$ was added dropwise $\mathrm{CH}_{3} \mathrm{COCl}(16.5 \mathrm{~mL})$ at $0{ }^{\circ} \mathrm{C}$ over $2 \mathrm{~h}$, and the resulting mixture was stirred at room temperature for $3 \mathrm{~h}$. The reaction mixture was poured to dilute hydrochloric acid solution $(5 \%, 500 \mathrm{~mL})$ and stirred for $30 \mathrm{~min}$. The aqueous layer was extracted by EtOAc $(3 \times 30 \mathrm{~mL})$ and the combined organic phases were washed successively by saturated aqueous $\mathrm{NaHCO}_{3}$, brine and dried (anhydrous $\mathrm{MgSO}_{4}$ ), The solution was concentrated under reduced pressure to yield $36.5 \mathrm{~g}(84 \%)$ acetate 3 , colorless oil. ${ }^{1} \mathrm{H}-\mathrm{NMR}\left(300 \mathrm{MHz}, \mathrm{CDCl}_{3}\right): \delta=5.37-5.32(\mathrm{~m}, 1 \mathrm{H}$, $=\mathrm{CH}-), 5.10-5.06(\mathrm{~m}, 1 \mathrm{H},=\mathrm{CH}-), 4.59\left(\mathrm{~d}, 2 \mathrm{H}, J=7.2 \mathrm{~Hz},-\mathrm{CH}_{2} \mathrm{O}-\right), 2.12-2.01\left(\mathrm{~m}, 7 \mathrm{H},-\mathrm{CH}_{2} \mathrm{CH}_{2-}\right.$, $\left.\mathrm{CH}_{3} \mathrm{CO}-\right), 1.70\left(\mathrm{~s}, 3 \mathrm{H},-\mathrm{CH}_{3}\right), 1.68\left(\mathrm{~s}, 3 \mathrm{H},-\mathrm{CH}_{3}\right), 1.60\left(\mathrm{~s}, 3 \mathrm{H},-\mathrm{CH}_{3}\right)$. ESI-MS $(\mathrm{m} / \mathrm{z}): 219.2(\mathrm{M}+\mathrm{Na})^{+}$.

(E)-5-(3,3-Dimethyloxiran-2-yl)-3-methylpent-2-enyl Acetate (4). A solution of $m$-chloroperbenzoic acid $(85 \%, 18.1 \mathrm{~g})$ in $\mathrm{CH}_{2} \mathrm{Cl}_{2}(160 \mathrm{~mL})$ was added to a solution of $3(15.0 \mathrm{~g}, 76.5 \mathrm{mmol})$ in $\mathrm{CH}_{2} \mathrm{Cl}_{2}$ $\left(235 \mathrm{~mL}\right.$ ) at $-5{ }^{\circ} \mathrm{C}$ over $2 \mathrm{~h}$. The resulting mixture was stirred at $0{ }^{\circ} \mathrm{C}$ for $2 \mathrm{~h}$. The white precipitate was formed during the reaction (mainly $m$-chlorobenzoic acid). The reaction mixture was diluted with saturated aqueous $\mathrm{NaHCO}_{3}(250 \mathrm{~mL})$ and the aqueous layer was extracted with $\mathrm{CH}_{2} \mathrm{Cl}_{2}(2 \times 30 \mathrm{~mL})$. The combined organic layer was washed with saturated aqueous $\mathrm{NaHCO}_{3}$, brine and dried (anhydrous $\mathrm{MgSO}_{4}$ ), and concentrated under reduced pressure. The residue was chromatographed on silica gel 
using 10\% EtOAc/petroleum ether, affording $11.8 \mathrm{~g}(72 \%)$ of 4 as a colorless oil. ${ }^{1} \mathrm{H}-\mathrm{NMR}(300 \mathrm{MHz}$, $\left.\mathrm{CDCl}_{3}\right): \delta=5.42-5.37(\mathrm{~m}, 1 \mathrm{H},=\mathrm{CH}-), 4.59$ (d, 2H, $\left.J=7.2 \mathrm{~Hz},-\mathrm{CH}_{2} \mathrm{O}-\right), 2.70$ (t, $1 \mathrm{H}, J=6.3 \mathrm{~Hz}$, oxirane-H ), 2.26-2.13 (m, 2H, $\left.-\mathrm{CH}_{2}-\right), 2.05$ (s, 3H, $\left.-\mathrm{CH}_{3} \mathrm{CO}-\right), 1.73\left(\mathrm{~s}, 3 \mathrm{H},-\mathrm{CH}_{3}\right), 1.70-1.63(\mathrm{~m}, 2 \mathrm{H}$, $\left.-\mathrm{CH}_{2}-\right), 1.31\left(\mathrm{~s}, 3 \mathrm{H},-\mathrm{CH}_{3}\right), 1.26\left(\mathrm{~s}, 3 \mathrm{H},-\mathrm{CH}_{3}\right)$. ESI-MS $(\mathrm{m} / \mathrm{z}): 235.2(\mathrm{M}+\mathrm{Na})^{+}$.

(E)-3-Methyl-6-oxohex-2-enyl acetate (5). To a stirred solution of $4(5.0 \mathrm{~g}, 23.6 \mathrm{mmol})$ in $\mathrm{Et}_{2} \mathrm{O}(80 \mathrm{~mL})$ was added dropwise $\mathrm{HIO}_{4} \cdot 2 \mathrm{H}_{2} \mathrm{O}(5.8 \mathrm{~g}, 25.4 \mathrm{mmol})$ in THF $(50 \mathrm{~mL})$ at $0{ }^{\circ} \mathrm{C}$ over $2 \mathrm{~h}$. The resulting mixture was stirred at $0{ }^{\circ} \mathrm{C}$ for $3 \mathrm{~h}$. Then the reaction mixture was diluted with water $(100 \mathrm{~mL})$ and the aqueous layer was extracted with $\mathrm{Et}_{2} \mathrm{O}(2 \times 30 \mathrm{~mL})$. All organic phases were combined and washed successively by saturated aqueous $\mathrm{NaHCO}_{3}$, brine and dried (anhydrous $\mathrm{MgSO}_{4}$ ), and concentrated under reduced pressure. The residue was chromatographed on silica gel using 10\% EtOAc/petroleum ether giving $3.2 \mathrm{~g}(80 \%)$ of 5 as a colorless oil. ${ }^{1} \mathrm{H}-\mathrm{NMR}\left(300 \mathrm{MHz}, \mathrm{CDCl}_{3}\right): \delta=9.78(\mathrm{~s}, 1 \mathrm{H},-\mathrm{CHO})$, 5.39-5.34 (m, 1H, =CH-), 4.59 (d, 2H, J=6.9 Hz, $\left.-\mathrm{CH}_{2} \mathrm{O}-\right), 2.61-2.56\left(\mathrm{~m}, 2 \mathrm{H},-\mathrm{CH}_{2}-\right), 2.40-2.36(\mathrm{~m}$, $\left.2 \mathrm{H},-\mathrm{CH}_{2}-\right), 2.05\left(\mathrm{~s}, 3 \mathrm{H}, \mathrm{CH}_{3} \mathrm{CO}-\right), 1.73\left(\mathrm{~s}, 3 \mathrm{H},-\mathrm{CH}_{3}\right)$. ESI-MS $(\mathrm{m} / \mathrm{z}): 193.1(\mathrm{M}+\mathrm{Na})^{+}$.

(E)-5-(1,3-Dioxolan-2-yl)-3-methylpent-2-enyl Acetate (6). A mixture of 5 (5.0 g, $29.4 \mathrm{mmol})$, ethylene glycol $(2.7 \mathrm{~g}, 43.5 \mathrm{mmol})$, and $p$-TsOH $(0.1 \mathrm{~g}, 0.6 \mathrm{mmol})$ in benzene $(80 \mathrm{~mL})$ was heated at reflux for $5 \mathrm{~h}$. After the reaction was quenched with saturated $\mathrm{NaHCO}_{3}$ solution $(40 \mathrm{~mL})$ and the solvent was evaporated, the residue was partitioned between EtOAc $(3 \times 200 \mathrm{~mL})$ and saturated aqueous $\mathrm{NaCl}(2 \times 100 \mathrm{~mL})$. The organic layer was dried over anhydrous $\mathrm{MgSO}_{4}$ and evaporated to give a residue which was purified by silica-gel chromatography (hexanes/EtOAc $=100: 1$ ) to afford 6 $(5.7 \mathrm{~g}, 90 \%)$ as a yellow oil. ${ }^{1} \mathrm{H}-\mathrm{NMR}\left(300 \mathrm{MHz}, \mathrm{CDCl}_{3}\right): \delta=5.40-5.35(\mathrm{~m}, 1 \mathrm{H},=\mathrm{CH}-), 4.86(\mathrm{t}, 1 \mathrm{H}$, $\left.J=4.8 \mathrm{~Hz},-\mathrm{OCH}(-\mathrm{O}-) \mathrm{CH}_{2}-\right), 4.58\left(\mathrm{~d}, 2 \mathrm{H}, J=7.2 \mathrm{~Hz},-\mathrm{CH}_{2} \mathrm{O}-\right)$, 3.99-3.94 (m, 2H, - $\left.\mathrm{OCH}_{2}-\right)$, 3.87-3.82 (m, $\left.2 \mathrm{H},-\mathrm{OCH}_{2}-\right), 2.17\left(\mathrm{t}, 2 \mathrm{H}, J=8.1 \mathrm{~Hz},-\mathrm{CH}_{2}-\right), 2.05$ (s, 3H, $\left.\mathrm{CH}_{3} \mathrm{CO}-\right), 1.82-1.75$ (m, 2H, $-\mathrm{CH}_{2}-$ ), $1.72\left(\mathrm{~s}, 3 \mathrm{H},-\mathrm{CH}_{3}\right)$. ESI-MS $(\mathrm{m} / \mathrm{z}): 237.1(\mathrm{M}+\mathrm{Na})^{+}$.

(E)-5-(1,3-Dioxolan-2-yl)-3-methylpent-2-en-1-ol (7). A mixture of 6 (5.0 g, $23.4 \mathrm{mmol})$, and anhydrous $\mathrm{K}_{2} \mathrm{CO}_{3}(0.7 \mathrm{~g}, 5.0 \mathrm{mmol})$ in $\mathrm{CH}_{3} \mathrm{OH}(100 \mathrm{~mL})$ was stirred at room temperature for $12 \mathrm{~h}$ (monitored by TLC, $\mathrm{R}_{f}=0.5$, EtOAc/petroleum ether $=1: 1$ ). Most of the solvent was evaporated in vacuo, the residue was diluted with water $(30 \mathrm{~mL})$ and extracted with $\mathrm{Et}_{2} \mathrm{O}(3 \times 20 \mathrm{~mL})$. The ethereal solution was combined and washed brine, dried (anhydrous $\mathrm{MgSO}_{4}$ ) and concentrated in vacuo to give the crude product, which was chromatographied over silica gel (EtOAc/petroleum ether, 20:80 $\rightarrow$ 40:60) to afford $3.4 \mathrm{~g}(82 \%)$ of 7 as a yellow oil. ${ }^{1} \mathrm{H}-\mathrm{NMR}\left(300 \mathrm{MHz}, \mathrm{CDCl}_{3}\right): \delta=5.46-5.41(\mathrm{~m}, 1 \mathrm{H},=\mathrm{CH}-)$, $4.86\left(\mathrm{t}, 1 \mathrm{H}, J=4.7 \mathrm{~Hz},-\mathrm{OC} \underline{\mathrm{H}}(-\mathrm{O}-) \mathrm{CH}_{2}\right.$ ), 4.13 (d, $\left.2 \mathrm{H}, J=6.9 \mathrm{~Hz},-\mathrm{CH}_{2} \mathrm{O}-\right), 3.99-3.95$ (m, 2H, $\left.-\mathrm{OCH}_{2}-\right), 3.87-3.83\left(\mathrm{~m}, 2 \mathrm{H},-\mathrm{OCH}_{2}-\right), 2.15\left(\mathrm{t}, 2 \mathrm{H}, J=8.0 \mathrm{~Hz},-\mathrm{CH}_{2}-\right), 1.85-1.75\left(\mathrm{~m}, 2 \mathrm{H},-\mathrm{CH}_{2^{-}}\right), 2.05$ (s, 3H, $\left.\mathrm{CH}_{3} \mathrm{CO}-\right), 1.69\left(\mathrm{~s}, 3 \mathrm{H},-\mathrm{CH}_{3}\right)$. ESI-MS $(\mathrm{m} / \mathrm{z}): 195.0(\mathrm{M}+\mathrm{Na})^{+}$.

(E)-5-(1,3-Dioxolan-2-yl)-3-methylpent-2-enyl 3-methylbut-3-enoate (10). A mixture of 7 (1.7 g, $10.0 \mathrm{mmol}), 9(1.0 \mathrm{~g}, 10.0 \mathrm{mmol})$, DCC (2.3 g, $12.0 \mathrm{mmol})$ and DMAP $(0.3 \mathrm{~g}, 2.5 \mathrm{mmol})$ in $\mathrm{CH}_{2} \mathrm{Cl}_{2}$ $(30 \mathrm{~mL})$ was stirred at room temperature for $12 \mathrm{~h}$ (monitored by TLC, $\mathrm{R}_{f}=0.8$, EtOAc/petroleum ether = 1:5). The white precipitate was filtered, and the filtrate was washed successively by $\mathrm{HCl}(5 \%)$, saturated $\mathrm{NaHCO}_{3}$, brine, dried (anhydrous $\mathrm{MgSO}_{4}$ ) and concentrated in vacuo to give crude product, which was purified by silica-gel chromatography (EtOAc/petroleum ether, 5:95) to afford $1.1 \mathrm{~g} \mathrm{(42 \% )}$ 
of 10 as light yellow oil. ${ }^{1} \mathrm{H}-\mathrm{NMR}\left(300 \mathrm{MHz}, \mathrm{CDCl}_{3}\right): \delta=5.40-5.35\left(\mathrm{~m}, 1 \mathrm{H},=\mathrm{CH}_{2}\right), 4.91-4.62(\mathrm{~m}$, $\left.3 \mathrm{H},=\mathrm{CH}_{2},=\mathrm{CH}-,-\mathrm{OC} \underline{\mathrm{H}}(-\mathrm{O}-) \mathrm{CH}_{2}-\right), 4.62-4.60\left(\mathrm{~d}, 2 \mathrm{H}, J=6.9 \mathrm{~Hz},-\mathrm{CH}_{2} \mathrm{O}-\right), 3.99-3.95(\mathrm{~m}, 2 \mathrm{H}$, $\left.-\mathrm{OCH}_{2}-\right), 3.87-3.82\left(\mathrm{~m}, 2 \mathrm{H},-\mathrm{OCH}_{2}\right.$ ), 3.03 (s, 2H, $\left.-\mathrm{CH}_{2} \mathrm{CO}-\right), 2.17$ (t, $\left.2 \mathrm{H}, J=8.1 \mathrm{~Hz},-\mathrm{CH}_{2}-\right), 1.82$ (s, $\left.3 \mathrm{H},-\mathrm{CH}_{3}\right), 1.80-1.75\left(\mathrm{~m}, 2 \mathrm{H},-\mathrm{CH}_{2}-\right), 1.72\left(\mathrm{~s}, 3 \mathrm{H},-\mathrm{CH}_{3}\right) .{ }^{13} \mathrm{C}-\mathrm{NMR}\left(150 \mathrm{MHz}, \mathrm{CDCl}_{3}\right): \delta=16.4,22.3$, $31.9,33.5,43.3,61.3,64.8,103.9,114.5,118.4,138.5,141.4,171.2$. ESI-MS $(m / z): 277.1(\mathrm{M}+\mathrm{Na})^{+}$. HRMS (ESI): calcd for $\mathrm{C}_{14} \mathrm{H}_{23} \mathrm{O}_{4}(\mathrm{M}+\mathrm{H})^{+}, 255.1596$, found 255.1603 .

(3S)-3-(2-(1,3-Dioxolan-2-yl)ethyl)-3-methyl-2-(prop-1-en-2-yl)pent-4-enoic Acid (11). A solution of 2 equiv. of LDA in dry THF $(3 \mathrm{~mL}, 2 \mathrm{M})$ was cooled to $-78{ }^{\circ} \mathrm{C}$. To this stirred solution was added 1.0 equiv. of the ester $10(0.76 \mathrm{~g}, 3 \mathrm{mmol})$, dropwise over $10 \mathrm{~min}$. Following the addition, the reaction mixture was stirred at $-78{ }^{\circ} \mathrm{C}$ for $10 \mathrm{~min}$ and the 2 equiv. of $\mathrm{Me}_{3} \mathrm{SiCl}(0.76 \mathrm{~mL}, 6 \mathrm{mmol})$ in $\mathrm{THF}(6 \mathrm{~mL})$ was added dropwisely to the reaction mixture for $10 \mathrm{~min}$. The reaction mixture was stirred at $-78{ }^{\circ} \mathrm{C}$ for $1.5 \mathrm{~h}$ and allowed to warm to $25^{\circ} \mathrm{C}$ for $2 \mathrm{~h}$. After the reaction was quenched with $1 \mathrm{~N} \mathrm{NaOH}(20 \mathrm{~mL})$ and the organic phase was washed with $1 \mathrm{~N} \mathrm{NaOH}(15 \mathrm{~mL})$, the aqueous phases were combined and acidified by $\mathrm{HCl}(5 \%)$ to $\mathrm{pH}=1$. the mixture was extracted with $\mathrm{Et}_{2} \mathrm{O}(3 \times 15 \mathrm{~mL})$, dried with anhydrous $\mathrm{MgSO}_{4}$, filtered and concentrated in vacuo to afford the crude acid, which was purified by silica gel chromatography $\left(5 \% \mathrm{MeOH} / \mathrm{CH}_{2} \mathrm{Cl}_{2}\right)$ to give $0.55 \mathrm{~g}(72 \%)$ of $\mathbf{1 1}$ as an inseparable mixture of diastereomers $(\mathrm{dr}=2: 1)$, as a light yellow oil. ${ }^{1} \mathrm{H}-\mathrm{NMR}\left(300 \mathrm{MHz}, \mathrm{CDCl}_{3}\right): \delta$ (mixture of two diastereomers $)=6.05$ and $5.84(\mathrm{dd}, 1 \mathrm{H}, J=10.8,17.5 \mathrm{~Hz},-\mathrm{CH}=), 5.12-4.95\left(\mathrm{~m}, 4 \mathrm{H},=\mathrm{CH}_{2},=\mathrm{CH}_{2}\right)$, $4.82\left(\mathrm{t}, 1 \mathrm{H}, J=2.1 \mathrm{~Hz},-\mathrm{OC} \underline{\mathrm{H}}(-\mathrm{O}-) \mathrm{CH}_{2}-\right), 3.97-3.89$ (m, 2H, $\left.-\mathrm{OCH}_{2^{-}}\right), 3.85-3.81$ (m, 2H, $\left.-\mathrm{OCH}_{2}-\right)$, $3.06(\mathrm{~s}, 1 \mathrm{H}, 4-\mathrm{H}), 1.85\left(\mathrm{~s}, 3 \mathrm{H},-\mathrm{CH}_{3}\right), 1.69-1.55\left(\mathrm{~m}, 4 \mathrm{H},-\mathrm{CH}_{2} \mathrm{CH}_{2}\right), 1.16$ and $1.11\left(\mathrm{~s}, 1 \mathrm{H},-\mathrm{CH}_{3}\right)$. ${ }^{13} \mathrm{C}-\mathrm{NMR}\left(150 \mathrm{MHz} \mathrm{CDCl}_{3}\right): \delta=19.4,23.8 / 24.5,28.8,32.5 / 33.4,42.0,61.2 / 61.8,63.6 / 64.8,104.8$, 114.0/114.3, 117.1/117.5, 139.7, 143.2/143.5, 177.4. HRMS (ESI): calcd for $\mathrm{C}_{14} \mathrm{H}_{23} \mathrm{O}_{4}(\mathrm{M}+\mathrm{H})^{+}, 255.1596$, found 255.1564 .

(3S)-3-(2-(1,3-Dioxolan-2-yl)ethyl)-3-methyl-2-(prop-1-en-2-yl)pent-4-en-1-ol (12). To a stirred solution of $\mathrm{LiAlH}_{4}(1.5 \mathrm{~g}, 39.3 \mathrm{mmol})$ in dry THF $(15 \mathrm{~mL})$ was added dropwise the inseparable mixture of $11(2.0 \mathrm{~g}, 7.9 \mathrm{mmol})$ in dry THF $(20 \mathrm{~mL})$ at $0{ }^{\circ} \mathrm{C}$ over $10 \mathrm{~min}$. The reaction mixture was stirred at room temperature for $5 \mathrm{~h}$ and allowed to warm to reflux for $1 \mathrm{~h}$. The mixture was quenched successively by $\mathrm{H}_{2} \mathrm{O}(1.5 \mathrm{~mL}), \mathrm{NaOH}(15 \%, 1.5 \mathrm{~mL})$ and $4.5 \mathrm{~mL} \mathrm{H}_{2} \mathrm{O}$ on the ice-bath condition and stirred at room temperature for $30 \mathrm{~min}$. The white precipitation was filtered and washed with $\mathrm{Et}_{2} \mathrm{O}$ $(2 \times 10 \mathrm{~mL})$. All the organic phases were combined, dried (anhydrous $\mathrm{MgSO}_{4}$ ), filtered and concentrated in vacuo to give the crude product, which was purified by silica gel chromatography (EtOAc/petroleum ether, 5:95) to afford $1.58 \mathrm{~g}(83 \%)$ of $\mathbf{1 2}$ as an inseparable mixture of diastereomers $(\mathrm{dr}=2: 1)$, light yellow oil. $\mathrm{R}_{f}=0.35$ (EtOAc/petroleum ether, 1:3). ${ }^{1} \mathrm{H}-\mathrm{NMR}\left(300 \mathrm{MHz}, \mathrm{CDCl}_{3}\right): \delta$ (mixture of two diastereomers) $=5.77$ and $5.72(\mathrm{dd}, 1 \mathrm{H}, J=10.8,17.5 \mathrm{~Hz},-\mathrm{CH}=), 5.11-4.79(\mathrm{~m}, 5 \mathrm{H}$, $\left.=\mathrm{CH}_{2},=\mathrm{CH}_{2},-\mathrm{OC} \underline{\mathrm{H}}(-\mathrm{O}-) \mathrm{CH}_{2}-\right), 3.95-3.93\left(\mathrm{~m}, 2 \mathrm{H},-\mathrm{OCH}_{2}-\right), 3.85-3.83\left(\mathrm{~m}, 2 \mathrm{H},-\mathrm{OCH}_{2}-\right), 3.77-3.59$ (m, $\left.2 \mathrm{H},-\mathrm{CH}_{2} \mathrm{OH}\right), 2.25-2.22(\mathrm{~m}, 1 \mathrm{H}, 4-\mathrm{H}), 1.79$ and $1.79\left(\mathrm{~s}, 3 \mathrm{H},-\mathrm{CH}_{3}\right), 1.57-1.48\left(\mathrm{~m}, 4 \mathrm{H},-\mathrm{CH}_{2} \mathrm{CH}_{2}-\right)$, 1.03 and $0.98\left(\mathrm{~s}, 1 \mathrm{H},-\mathrm{CH}_{3}\right) .{ }^{13} \mathrm{C}-\mathrm{NMR}\left(150 \mathrm{MHz}, \mathrm{CDCl}_{3}\right): \delta=17.7,25.3,28.5,35.4,41.1,60.8 / 61.9$, $62.4,64.9 / 65.4,102.2,110.3,113.1,144.7,149.7$. HRMS (ESI): calcd for $\mathrm{C}_{14} \mathrm{H}_{25} \mathrm{O}_{3}(\mathrm{M}+\mathrm{H})^{+}$, 241.1804, found 241.1794. 
(3S)-5-(Iodomethyl)-4,6-dimethyl-4-vinylhept-6-enal (14). To a stirred solution of the inseparable mixture of $12(1.3 \mathrm{~g}, 5.4 \mathrm{mmol})$ in dry pyridine $(20 \mathrm{~mL})$ was added dropwise tosyl chloride $(1.5 \mathrm{~g}$, $7.9 \mathrm{mmol})$ in $\mathrm{CH}_{2} \mathrm{Cl}_{2}(15 \mathrm{~mL})$ at ice-water temperature over $10 \mathrm{~min}$. Then the reaction mixture was stirred at room temperature for additional $12 \mathrm{~h}$. The reaction mixture was quenched with $10 \% \mathrm{HCl}(30 \mathrm{~mL})$ and extracted with $\mathrm{CH}_{2} \mathrm{Cl}_{2}(3 \times 15 \mathrm{~mL})$. All the organic phases were combined and washed successively by saturated $\mathrm{NaHCO}_{3}$, brine, and dried over anhydrous $\mathrm{MgSO}_{4}$, filtered and concentrated in vacuo to give the crude product 13, which was used directly in the next step without further purification. $\mathrm{R}_{f}=0.60$ (EtOAc/petroleum ether, 1:3). A solution of the inseparable mixture of 13, NaI $(3.9 \mathrm{~g})$ in acetone $(25 \mathrm{~mL})$ was allowed to reflux for $40 \mathrm{~h}$ in dark condition. After the reaction mixture was cooled to room temperature, the precipitation was filtered and concentrated to give brown oil, which was added saturated $\mathrm{Na}_{2} \mathrm{~S}_{2} \mathrm{O}_{3}(30 \mathrm{~mL})$ and extracted with ether $(3 \times 15 \mathrm{~mL})$. The combined organic phases were washed by brine and dried over anhydrous $\mathrm{MgSO}_{4}$, filtered and concentrated in vacuo to give the crude iodide product, $\mathrm{R}_{f}=0.80$ (EtOAc/petroleum ether, 1:5). Then the solution of the crude iodide product, $p$-TsOH $(0.1 \mathrm{~g})$ in $10 \% \mathrm{H}_{2} \mathrm{O} /$ acetone $(10 \mathrm{~mL})$ was allowed to reflux for $2 \mathrm{~h}$. Most of acetone was evaporated in vacuo, the residue was diluted with saturated $\mathrm{NaHCO}_{3}$, and extracted with ether $(3 \times 10 \mathrm{~mL})$. The combined ether was washed by brine, dried over anhydrous $\mathrm{MgSO}_{4}$, filtered and concentrated to give the crude product, which was purified by silica gel chromatography (EtOAc/petroleum ether, 2:98) to afford inseparable mixture of 14 (0.38 g, 23\% in 3 steps). light yellow oil. $\mathrm{R}_{f}=0.50$ (EtOAc/petroleum ether, 1:8). Trials were performed to establish the separability of the diastereoisomers using an appropriate chromatographic column size. These attempts have not been successful so far and the diastereomeric ratio of $\mathbf{1 4}$ was only raised to 3:1. ${ }^{1} \mathrm{H}-\mathrm{NMR}\left(300 \mathrm{MHz}, \mathrm{CDCl}_{3}\right): \delta$ (mixture of two diastereomers) $=5.71$ and $5.64(\mathrm{dd}, 1 \mathrm{H}, J=10.8$, $17.4 \mathrm{~Hz},-\mathrm{CH}=)$, 5.22-4.79 (m, 4H, $\left.=\mathrm{CH}_{2},=\mathrm{CH}_{2}\right), 3.53-3.49\left(\mathrm{~m}, 1 \mathrm{H},-\mathrm{CH}_{2} \mathrm{I}\right), 3.15-3.06\left(\mathrm{~m}, 1 \mathrm{H},-\mathrm{CH}_{2} \mathrm{I}\right)$, 2.45-2.30 (m, 3H, $-\mathrm{CH}_{2} \mathrm{CHO}$ and 5-H), 1.65-1.82 (m, 5H, $\left.-\mathrm{CH}_{2}-,-\mathrm{CH}_{3}\right), 1.04$ and $0.97\left(\mathrm{~s}, 1 \mathrm{H},-\mathrm{CH}_{3}\right)$. HRMS (ESI): calcd for $\mathrm{C}_{12} \mathrm{H}_{20} \mathrm{IO}(\mathrm{M}+\mathrm{H})^{+}, 307.0559$, found 307.0941 .

( \pm -Geijerone (1) and its 5-epimer. A solution of the inseparable mixture of $\mathbf{1 4}(0.5 \mathrm{~g}, 1.6 \mathrm{mmol})$ in dry THF $(10 \mathrm{~mL})$ was cooled to $-78{ }^{\circ} \mathrm{C}$. To this stirred solution was added dropwise 3.0 equiv. of $n$-BuLi (1.6 M/L in $n$-hexane, $3.1 \mathrm{~mL}, 4.8 \mathrm{mmol})$ over $10 \mathrm{~min}$. The reaction mixture was stirred at $-78{ }^{\circ} \mathrm{C}$ for additional $1 \mathrm{~h}$. Then the reaction mixture was quenched with saturated $\mathrm{NH}_{4} \mathrm{Cl}(30 \mathrm{~mL})$, and the organic phase was separated. The aqueous phase was extracted with $\mathrm{Et}_{2} \mathrm{O}(3 \times 10 \mathrm{~mL})$. All organic phases were combined and washed by brine and dried over anhydrous $\mathrm{MgSO}_{4}$, filtered and concentrated in vacuo to afford inseparable diastereomeric mixture of crude 15, light yellow oil. HRMS (ESI): calcd for $\mathrm{C}_{12} \mathrm{H}_{21} \mathrm{O}(\mathrm{M}+\mathrm{H})^{+}, 181.1592$, found 181.1584 .

A solution of the inseparable mixture of $15(70 \mathrm{mg}, 0.6 \mathrm{mmol})$ in $10 \mathrm{~mL}$ of $\mathrm{CH}_{2} \mathrm{Cl}_{2}$ was added dropwise $\mathrm{PCC}(0.5 \mathrm{~g}, 2.3 \mathrm{mmol})$ in $\mathrm{CH}_{2} \mathrm{Cl}_{2}(10 \mathrm{~mL})$ at room temperature over $10 \mathrm{~min}$, and the reaction mixture was stirred at room temperature for additional $2 \mathrm{~h}$. Then the reaction mixture was diluted with $10 \mathrm{~mL}$ of diethyl ether, filtered and concentrated in vacuo to give the crude product, which was purified by silica gel chromatography (EtOAc/petroleum ether, 2:98) to afford an inseparable diastereomeric mixture of 1 and its 5-epimer (40 mg, 60\%), colorless oil. $\mathrm{R}_{f}=0.75$ (EtOAc/petroleum ether, 1:6). ${ }^{1} \mathrm{H}-\mathrm{NMR}\left(300 \mathrm{MHz}, \mathrm{CDCl}_{3}\right): \delta$ (as a mixture with 5-epimer) $=5.75$ and $5.65(\mathrm{dd}, 1 \mathrm{H}$, $J=10.6,17.3 \mathrm{~Hz}, 1-\mathrm{H}), 5.11-4.65$ (m, 4H, 2-H, 3-H), 2.60-2.25 (m, 4H, 6-H, 8-H), 1.78-1.63 (m, 3H, 
5-H, 11-H), 1.56-1.48 and 1.36-1.23 (m, 2H, 9-H), 0.91 and 0.90 (s, 3H, 12-H). ${ }^{13} \mathrm{C}-\mathrm{NMR}(150 \mathrm{MHz}$, $\left.\mathrm{CDCl}_{3}\right): \delta=13.9,22.4 / 26.0,27.7 / 29.7,32.3 / 32.4,38.1,42.7,56.1 / 57.4,112.6 / 112.7,113.7 / 114.3$, 143.8/144.7, 144.8/145.7, 211.8/211.9. ESI-MS $(\mathrm{m} / \mathrm{z})$ : $201.1(\mathrm{M}+\mathrm{Na})^{+}$. HRMS (ESI): calcd for $\mathrm{C}_{12} \mathrm{H}_{19} \mathrm{O}(\mathrm{M}+\mathrm{H})^{+}, 179.1436$, found 179.1400 .

\section{Conclusions}

In conclusion, an alternative synthetic route of both diastereomers of ( \pm )-geijerone (1) via a 13-step process was achieved starting from the commercially available geraniol (2). The Ireland-Claisen rearrangement $(\mathbf{1 0} \rightarrow \mathbf{1 1})$ bearing the syn- and anti-1,2-dialkenyl carboxylic acid, and the intramolecular Barbier reaction affording the new intramolecular $\mathrm{C}-\mathrm{C}$ bond (15) were the key steps. The newly formed syn- and anti-1,2-dialkenylcyclohexane strategy used for the synthesis of ( \pm )-geijerone (1) and a diastereoisomeric mixture with its 5-epimer allows rapid access to various epimers and analogues of elemene-type products.

\section{Acknowledgments}

This work was supported by National Key Technologies R\&D Program of China (2009ZX09103-057), Program for Innovative Research Team of the Ministry of Education and Program for Liaoning Innovative Research Team in University (IRT1073).

\section{Author Contributions}

Conceived and designed the experiments: Jinhua Dong, Dawei Liang. Performed the experiments: Dawei Liang, Nana Gao and Wei Liu. Analyzed the data: Dawei Liang, Jinhua Dong. Wrote the paper: Dawei Liang, Jinhua Dong.

\section{Conflicts of Interest}

The authors declare no conflict of interest.

\section{References}

1. Newman, D.J. Natural products as leads to potential drugs: An old process or the new hope for drug discovery? J. Med. Chem. 2008, 51, 2589-2599.

2. Choi, H.S.; Sawamura, M. Effects of storage conditions on the composition of Citrus tamurana Hort. ex Tanaka (hyuganatsu) essential oil. Biosci. Biotechnol. Biochem. 2002, 66, 439-443.

3. Kweka, E.J.; Nyindo, M.; Mosha, F.; Silva, A.G. Insecticidal activity of the essential oil from fruits and seeds of Schinus terebinthifolia Raddi against African malaria vectors. Parasite. Vector. 2011, 4, 1-10.

4. Djabou, N.; Allali, H.; Battesti, M.J.; Tabti, B.; Costa, J.; Muselli, A.; Varesi, L. Chemical and genetic differentiation of two Mediterranean subspecies of Teucrium scorodonia L. Phytochemistry 2011, 74, 123-132. 
5. Birch, A.J.; Grimshaw, J.; Penfold, A.R.; Sheppard, N.; Speake, R.N. An independent confirmation of the structure of geijerene by physical methods. J. Chem. Soc. 1961, 2286-2291, doi:10.1039/JR9610002286.

6. Chai, M.C.; Wang, S.K.; Dai, C.F.; Duh, C.Y. A cytotoxic lobane diterpene from the formosan soft coral Sinularia inelegans. J. Nat. Prod. 2000, 63, 843-844.

7. Terada, Y.; Yamamura, S. Stereochemical studies on germacrenes: An application of molecular mechanics calculations. Tetrahedron Lett. 1979, 35, 3303-3306.

8. Terada, Y.; Yamamura, S. An Application of molecular mechanics calculations on thermal reactions of ten-membered ring Sesquit. Bull. Chem. Soc. Jpn. 1982, 55, 2495-2499.

9. Machado, F.B.; Yamamoto, R.E.; Zanoli, K.; Nocchi, S.R.; Novello, C.R.; Schuquel, I.T.A.; Sakuragui, C.M.; Luftmann, H.; Ueda-Nakamura, T.; Nakamura, C.V.; et al. Evaluation of the antiproliferative activity of the leaves from Arctium lappa by a bioassay-guided fractionation. Molecules 2012, 17, 1852-1859.

10. Yang, H.; Wang, X.S.; Yu, L.L.; Zheng, S. The antitumor activity of elemene is associated with apoptosis. Chin. J. Oncol. 1996, 18, 169-172.

11. Srivastava, S.K.; Abraham, A.; Bhat, B.; Jaggi, M.; Singh, A.T.; Sanna, V.K.; Singh, G.; Agarwal, S.K.; Mukherjee, R.; Burman, A.C. Synthesis of 13-amino costunolide derivatives as anticancer agents. Bioorg. Med. Chem. Lett. 2006, 16, 4195-4199.

12. Choi, B.G.; Kwak, E.Y.; Chung, B.H.; Cho, W.J.; Cheon, S.H. Synthesis of sesquiterpene derivatives as potential antitumor agents; elemane derivatives. Arch. Pharm. Res. 1999, 22, 575-578.

13. Liu, J.; Zhang, Y.; Qu, J.L.; Xu, L.; Hou, K.Z.; Zhang, J.D.; Qu, X.J.; Liu, Y.P. â-Elemene-induced autophagy protects human gastric cancer cells from undergoing apoptosis. BMC Cancer 2011, 11, 183.

14. Chen, W.; Lu, Y.; Wu, J.; Gao, M.; Wang, A.; Xu, B. Beta-elemene inhibits melanoma growth and metastasis via suppressing vascular endothelial growth factor-mediated angiogenesis. Cancer Chemoth. Pharmacol. 2011, 67, 799-808.

15. Xie, C.Y.; Yang, W.; Ying, J.; Ni, Q.C.; Pan, X.D.; Dong, J.H.; Li, K.; Wang, X.S. B-Cell Lymphoma-2 over-expression protects $\ddot{a}$-elemene-induced apoptosis in human lung carcinoma mucoepidermoid cells via a nuclear factor Kappa B-related pathway. Biol. Pharm. Bull. 2011, 34, 1279-1286.

16. Wang, X.W. Elemene: Antineoplastic. Drugs Future 1998, 23, 266-270.

17. Li, D.J.; Shao, J.L.; Zhang, Z.L.; Ao, J.H.; Zhang, Y.; Gu, M.; Chen, T. Pharmacological studies on elemene and the clinical application. Lishizhen Med. Mater. Med. Res. 2001, 12, 1123-1124.

18. Zhao, R.B.; Zhao, Y.F.; Song, G.Q.; Wu, Y.L. Double michael reaction of carvone and its derivatives. Tetrahedron Lett. 1990, 31, 3559-3562.

19. Zhao, Y.F.; Zhao, R.B.; Wu, Y.L. Double michael reaction of carvone and its utilization in chiral synthesis of natural products. Huaxue Xuebao 1994, 52, 823-830.

20. Patil, L.J.; Rao, A.S. Synthesis of $\hat{a}$-elemene and elemol. Tetrahedron Lett. 1967, 8, 2273-2275.

21. McMurry, J.E.; Kocovsky, P. Synthesis of helminthogermacrene and $\hat{a}$-elemene. Tetrahedron Lett. 1985, 26, 2171-2172.

22. Corey, E.J.; Roberts, B.E.; Dixon, B.R. Enantioselective total synthesis of $\hat{a}$-elemene and fuscol based on enantiocontrolled Ireland-Claisen rearrangement. J. Am. Chem. Soc. 1995, 117, 193-196. 


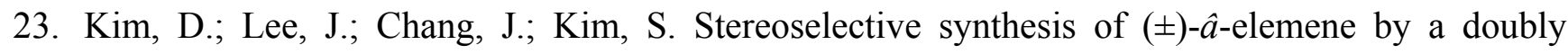
diastereodifferentiating internal alkylation: A remarkable difference in the rate of enolization between syn and anti esters. Tetrahedron 2001, 57, 1247-1252.

24. Barrero, A.F.; Herrador, M.M.; Quílez del Moral, J.F.; Arteaga, P.; Meine, N.; Pérez-Morales, M.C.; Catalán, J.V. Efficient synthesis of the anticancer $\hat{a}$-elemene and other bioactive elemanes from sustainable germacrone. Org. Biomol. Chem. 2011, 9, 1118-1125.

25. Kim, D.; Kim, H.S. Stereoselective construction of functionalized cis-1,2-dialkyl-cyclohexanecarboxylates: A novel synthesis of $( \pm)$-geijerone and $\tilde{a}$-elemene. J. Org. Chem. 1987, 52, 4633-4634.

26. Kato, M.; Kurihara, H.; Yoshikoshi, A. Total synthesis of racemic geijerone and $\tilde{a}$-elemene. J. Chem. Soc. Perkin Trans. 1 1979, 2740-2743.

27. Kodd, D.S.; Oehlschlager, A.C.; Georgopapadakou, N.H.; Polak, A.M.; Hartman, P.G. Synthesis of inhibitors of 2,3-oxidosqualene-lanosterol cyclase. 2. Cyclocondensation of $\tilde{a}$-, $\ddot{a}$-unsaturated $\hat{a}$-keto esters with imines. J. Org. Chem. 1992, 57, 7226-7234.

28. Davis, C.E.; Bailey, J.L.; Lockner, J.W.; Coates, R.M. Regio- and stereoselectivity of diethylaluminum azide opening of trisubstituted epoxides and conversion of the $3^{\circ}$ azidohydrin adducts to isoprenoid aziridines. J. Org. Chem. 2003, 68, 75-82.

29. Ireland, R.E.; Mueller, R.H.; Willard, A.K. The ester enolate Claisen rearrangement. Stereochemical control through stereoselective enolate formation. J. Am. Chem. Soc. 1976, 98, 2868-2877.

30. Koch, G.; Janser, P.; Kottirsch, G.; Romero-Giron, E. Highly diastereoselective Lewis acid promoted Claisen-Ireland rearrangement. Tetrahedron Lett. 2002, 43, 4837-4840.

31. Cooke, M.P., Jr.; Houpis, I.N. Metal-halogen exchange-initiated cyclization of iodo carbonyl compounds. Tetrahedron Lett. 1985, 26, 4987-4990.

32. Kihara, M.; Kashimoto, M.; Kobayashi, Y.; Kobayashi, S. A new intramolecular Barbier reaction of N-(2-iodobenzyl)phenacylamines: A convenient synthesis of 1,2,3,4-tetrahydroisoquinomn-4-ols. Tetrahedron Lett. 1990, 31, 5347-5348.

33. Zhang, W.; Dowd, P. Intramolecular Barbier reaction of a 3-(3'-bromopropyl) bicyclo[2.2.2]oct-5en-2-one. Tetrahedron Lett. 1993, 34, 2095-2098.

34. Ramón, D.J.; Yus, M. Carbamoyl and thiocarbamoyl lithium: A new route by naphthalenecatalysed chlorine-lithium exchange. Tetrahedron Lett. 1993, 34, 7115-7118.

35. Ennis, D.S.; Lathbury, D.C.; Wanders, A.; Watts, D. Scale-up of an intermolecular Barbier Reaction. Org. Process. Res. Dev. 1998, 2, 287-289.

36. Saito, T.; Takeuchi, T.; Matsuhashi, M.; Nakata, T. Chromone derivatives from the leaves of Nicotiana tabacum and their anti-Tobacco Mosaic Virus Activities. Heterocycles 2007, 72, 151-156.

Sample Availability: Samples of the compounds 1, 3-7, 9-12 and $\mathbf{1 4}$ are available from the authors.

(C) 2014 by the authors; licensee MDPI, Basel, Switzerland. This article is an open access article distributed under the terms and conditions of the Creative Commons Attribution license (http://creativecommons.org/licenses/by/3.0/). 